CASE REPORT

右腕頭静脈近傍に認めた中縦隔原発

malignant peripheral nerve sheath tumor $の 1$ 切除例

\author{
大村彰勲 1 渡 洋和 1 坂田龍平 1 ・川岸紗千 1 -田中 諒 1 - \\ 木村 亨 $1 \cdot$ 馬庭知弘 $1 \cdot$ 本間圭一郎 $2 \cdot$ 岡見次郎 1
}

\title{
Visceral Mediastinal Primary Nerve Sheath Tumor Located near the Right Brachiocephalic Vein
}

Akiisa Omural; Hirokazu Watari1; Ryuhei Sakata1; Sachi Kawagishi1; Ryo Tanaka1; Toru Kimura ${ }^{1}$; Tomohiro Maniwa ${ }^{1}$; Keiichiro Honma2; Jiro Okami1

${ }^{1}$ Department of General Thoracic Surgery, ${ }^{2}$ Department of Diagnostic Pathology and Cytology, Osaka International Cancer Institute, Japan.

ABSTRACT - Background. Malignant peripheral nerve sheath tumor (MPNST) is an uncommon malignant schwannoma, and some rare cases of MPNST in the mediastinum have been reported. Case. The patient was a woman in her 60s. An abnormal shadow was incidentally detected on chest X-ray, and the patient was referred to our institution. The tumor was located in the area between the right upper lobe of the lung and the right brachiocephalic vein, with a diameter of $53 \mathrm{~mm}$, and positron emission tomography-computed tomography (PET-CT) showed a fluorodeoxyglucose (FDG) uptake with a maximum standardized uptake value of 32.9 in the tumor. A transbronchial biopsy was performed. A pathological examination of the biopsy specimen showed no evidence of an epithelial tumor. We diagnosed the patient with a malignant tumor suspected to be MPNST or lung sarcoma. We decided to perform surgery. We resected the tumor via open thoracotomy. Due to the involvement of the right phrenic nerve, the right phrenic nerve was resected. The permanent pathological specimen showed dense proliferation of spindle cells with atypical mitoses, and immunohistochemistry was weakly positive for S100 and positive for SOX10. The pathological diagnosis was MPNST of mediastinal origin. The postoperative course was uneventful. The patient was alive without recurrence at one year after surgery. Conclusion. We experienced a case of resection of an MPNST of visceral mediastinal primary origin. In cases where a tumor suspected of being an MPNST on a preoperative examination is adjacent to a great vessel, thorough preoperative preparation, including vessel replacement with synthetic graft, should be performed to ensure complete resection of the tumor.

KEY WORDS — Mediastinal tumor, Malignant peripheral nerve sheath tumor

(JJLC. 2022;62:44-49)

Corresponding author: Akiisa Omura.

Received June 30, 2021; accepted September 30, 2021.

要旨——背 景. Malignant peripheral nerve sheath tumor（MPNST）は希少な悪性神経鞘腫であり，稀に縦隔 内に MPNST を認める症例も報告されている. 症例. 症 例は 60 歳代, 女性. 近医の胸部 X 線で胸部異常陰影を指 摘され，当院に紹介となった. 腫瘍は右肺上葉と右腕頭 静脈との間隙に存在し長径 $53 \mathrm{~mm}$ であり, PET-CT で同 腫瘍にSUVmax 32.9 の FDG 集積を認めた。気管支鏡下 生検で上皮性腫瘍の所見を認めず MPNST や肺肉腫を
疑う悪性所見を認め, 手術加療の方針となった. 開胸下 腫瘍切除術を行い, 右横隔神経への浸潤を認めていたた め右横隔神経を合併切除した。永久病理標本にて紡錘形 細胞が密に増殖し異型核分裂像を認め, 免疫染色で S 100 弱陽性, SOX10陽性であり, 病理診断は縦隔原発 MPNSTであった. 術後経過は良好であり, 現在も術後 1 年無再発生存中である。結論. 右中縦隔原発の MPNSTの 1 切除例を経験した。術前検査において 
MPNST である可能性が疑われる腫瘍が大血管に隣接し ている場合は，腫瘍の完全切除を行うべく人工血管置換
を含む最大限の術前準備を行うべきである. 索引用語—— 縦隔腫瘍, 悪性末梢神経鞘腫

\section{はじめに}

Malignant peripheral nerve sheath tumor （MPNST）は稀な悪性軟部組織腫瘍であり，胸腔内にお いては後縦隔に発生することが多いが，中縦隔に認める ことは極めて稀である，MPNST は過去の文献において 断端陰性による完全切除が予後を改善させることが示唆 されており, 今回我々は中縦隔に認めた MPNSTに対し て腫瘍切除術を施行したため報告する.

\section{症例}

症例 : 60 歳代, 女性.

主訴：なし.

既往歴：両側豊胸術後 (抜去後).

家族歴：特記事項なし.

喫煙歴：40 本 $/$ 日 $\times 47$ 年, 喫煙係数 1880 .

職業: 飲食接待業 (自営).

現病歴：かかりつけ医で撮影された検診目的の胸部 X 線写真において右上肺野に異常陰影を認め, 当センター 呼吸器内科に紹介受診となった。気管支鏡検査において

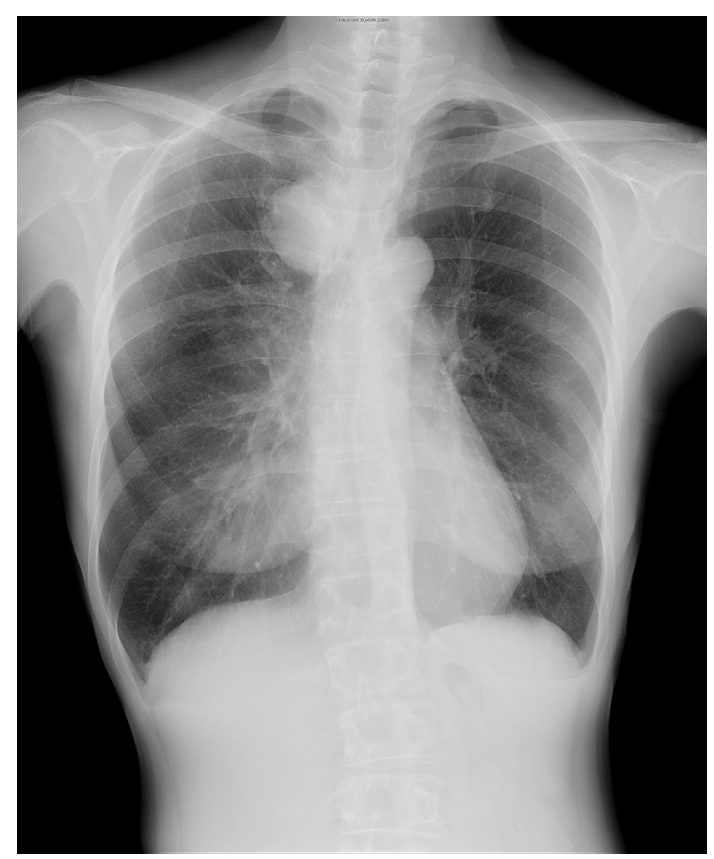

Figure 1. Chest X-ray findings on the initial examination. There is an abnormal shadow on the right side of the superior mediastinal zone.
腫瘍に対して気管支鏡下生検を施行し悪性所見を認め,

精査加療目的に当科紹介となった。

現症：意識清明, Performance Status 1, 身長 $159 \mathrm{~cm}$, 体重 $41.6 \mathrm{~kg}$, 血圧 110/85 mmHg, 脈拍 81/分, $\mathrm{SpO}_{2} 98 \%$ (room air). 明らかな皮䖉病変を認めなかった.

術前検査所見 : CEA $3.1 \mathrm{ng} / \mathrm{ml}$, CYFRA $1.6 \mathrm{ng} / \mathrm{ml}$,

ProGRP $25.7 \mathrm{pg} / \mathrm{ml}$, その他の特記事項なし.

呼吸機能検査: $\mathrm{VC} 2.54 l, \mathrm{FVC} 2.61 l, 1$ 秒量 $1.54 l$.

心電図 : HR 74 回/分, 洞調律.

心エコー：EF 70\%，その他に異常所見を認めなかっ た.

胸部単純 $X$ 線写真 : 右上肺野内側に縦隔陰影と連続 する腫瘤影を認めた（Figure 1).

胸部造影 $\mathrm{CT}$ ：右肺上葉と右腕頭静脈との間隙に, 長 径 $53 \mathrm{~mm}$ 大の不均一に造影される腫瘤を認めた. 上葉の 末梢肺実質は腫瘍による閉塞性肺炎を認めた。右腕頭静 脈後壁と広範に隣接しており, 浸潤の可能性があった. 右無名静脈とも隣接していたが, 明らかな血流障害を示 唆する所見を認めなかった（Figure 2).

PET-CT : 右上縦隔の辺縁不整な腫瘤影にFDG の異

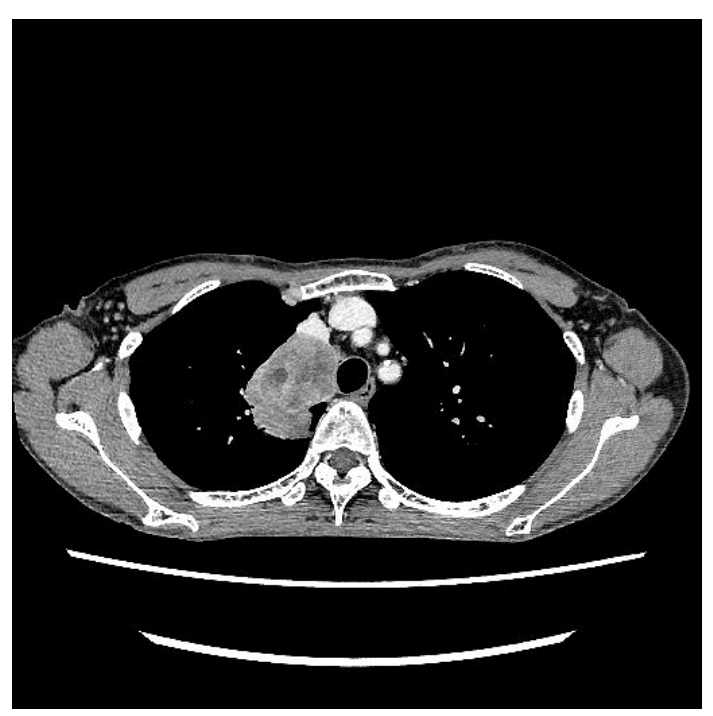

Figure 2. Chest CT findings. A 53-mm-long heterogeneously contrasted mass is noted in the area between the right upper lobe of the lung and the right brachiocephalic vein. The tumor is adjacent to the right brachiocephalic vein and could be involved. 


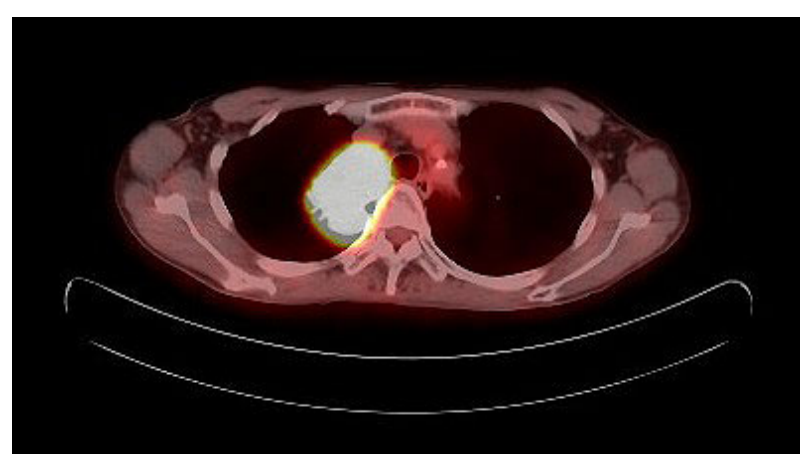

Figure 3. Positron emission tomography-computed tomography (PET-CT) findings. An abnormal fluorodeoxyglucose (FDG) uptake in the visceral mediastinal mass shadow can be seen.

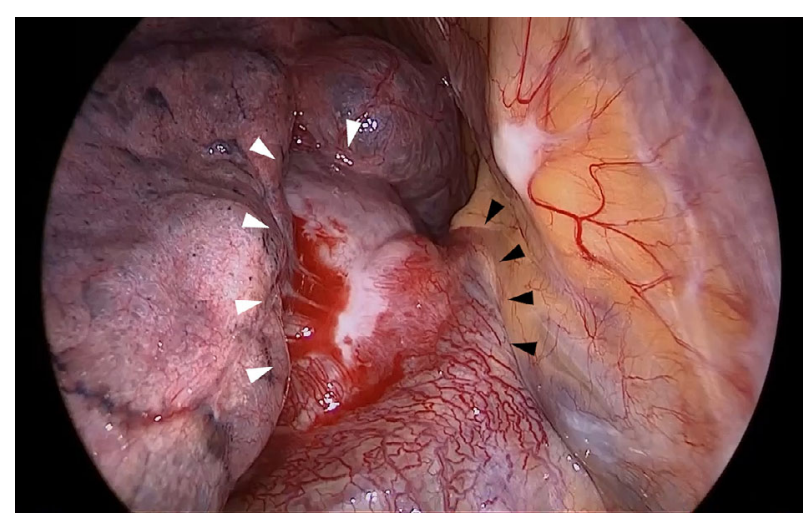

Figure 4. Thoracoscopic findings. The tumor (white arrowheads) is located in the area between the right upper lobe of the lung and the mediastinum, with adhesions to the right upper lobe of the lung and the right brachiocephalic vein (black arrowheads).

常集積（SUVmax 32.9）を認めた（Figure 3).

EBUS-TBNA 病理標本所見：核の大小不同を伴う異 型細胞増殖を認め，悪性腫瘍を考える所見であった，免 疫染色で, TTF-1 陰性, p40 陰性, BRG1 陽性, SOX10 陽性, S100 陽性であり, clear cell sarcoma や MPNST などが鑑別組織型として挙げられた.

当科や呼吸器内科による協議や, 当センターの肉腫希 少癌カンファレンスにて, 生検標本のみでは組織型を特 定できなかったこと，および上記鑑別疾患においては化 学療法が奏効する可能性が低いと考えられたことから, 術前治療を行わず腫瘍切除を行う方針となった．腫瘍は 右腕頭静脈への浸潤が疑われ，心臓血管外科へ応援を依 頼し, 右腕頭静脈一右心耳の人工血管吻合下での右腕頭 静脈合併切除をも想定した手術を計画した. まずは胸腔 鏡で腫瘍と右肺や縦隔との位置関係や癒着・浸潤を評価

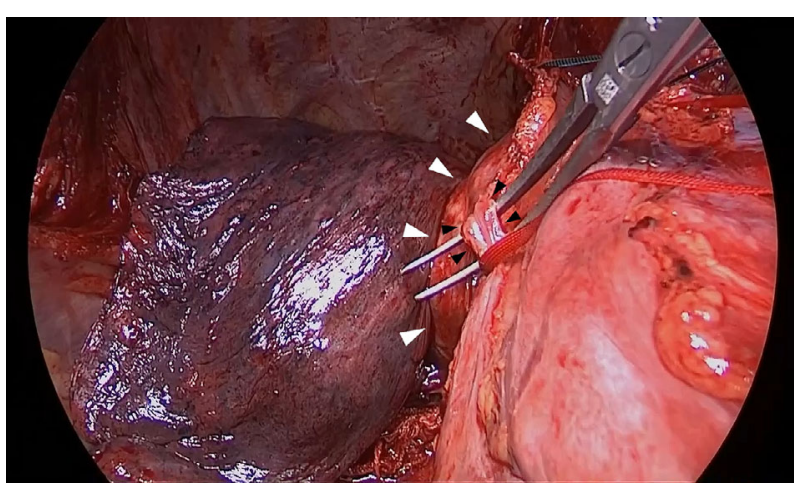

Figure 5. Due to the involvement of the right phrenic nerve (black arrowheads) with the tumor (white arrowheads), the right phrenic nerve was resected.

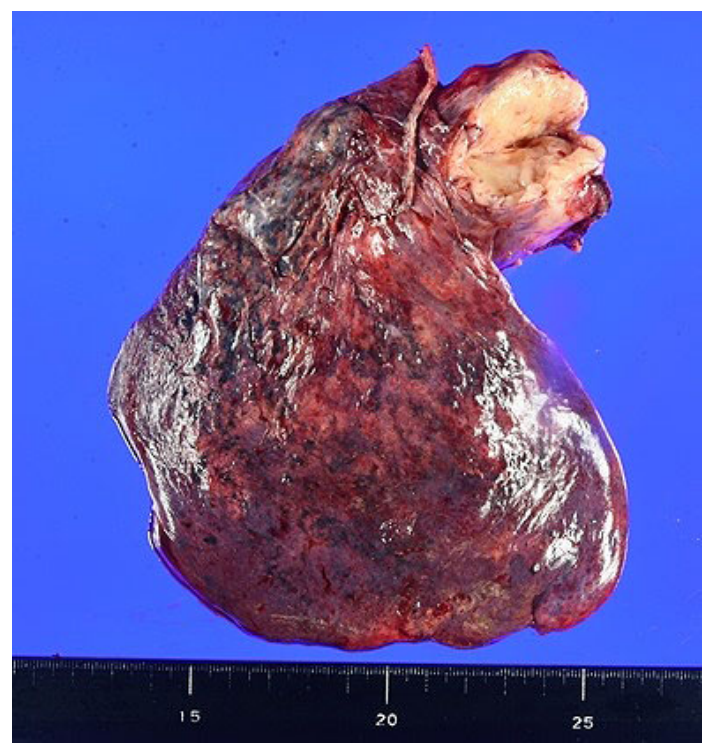

Figure 6. Resection specimen of the tumor and right upper lung lobe. A grayish-white, substantial, well-demarcated mass can be seen.

したのち，大血管操作が必要であると考えられた場合に 胸骨正中切開に移行する方針とした.

手術: 分離肺換気, 全身麻酔および硬膜外麻酔, 左側 臥位で手術を開始した. 中心静脈カテーテルを右鼠径に 確保した. 第 4 肋間に $6 \mathrm{~cm}$ の小開胸創をおき, 胸腔鏡を 挿入し観察した. 胸腔内は明らかな胸水貯留や播種病変 を認めず, 開胸時胸腔内洗浄細胞診は陰性であった. 腫 瘍は右肺上葉と縦隔との間隙に存在し, 右肺上葉や右腕 頭静脈と広範に癒着を認め, 奇静脈とも癒着を認め, 癒 着部は微細な側副血行が新生していた (Figure 4). 肺尖 部と壁側胸膜とも一部癒着を認めていた。原発性肺悪性 腫瘍の可能性も考えられたため, 右肺上葉切除および縦 隔リンパ節郭清を行う方針とした。腫瘍の癒着および浸 

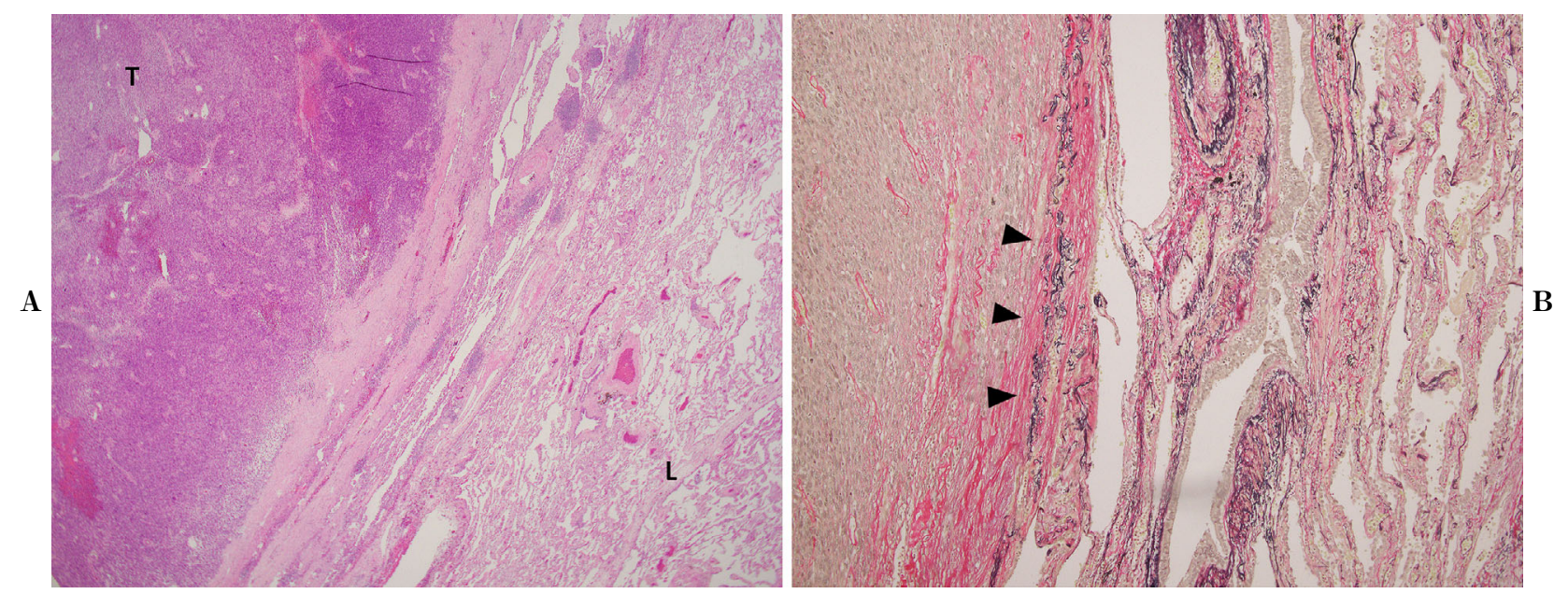

Figure 7. Hematoxylin-eosin $(\times 100, \mathbf{A})$ and Elastica van Gieson $(\mathrm{EVG})$ stain $(\times 100, \mathbf{B})$ show that there is no invasion to the lung $(\mathrm{L})$ by the tumor cells $(\mathrm{T})$ beyond the pleural elastic fibers (black arrowheads).

潤の評価や，腫瘍剥離処理を良好な視野で安全に遂行す るために, Masaoka らにより提唱 1 された前方アプロー チ（trap-door 法）での胸骨正中切開下の開胸手術へと移 行する方針とした。仰臥位とし，胸骨正中切開に右襟状 切開を加え, 第 4 胁間の皮切を延長し, コの字型の皮切 とした上で開胸して右胸壁を牽引し, trap-door 法にて視 野を得た. その後, 上大静脈, 右腕頭静脈, 奇静脈のテー ピングを行い，右肺上葉の各脈管を処理した，腫瘍には 右横隔神経が流入しており，同神経への腫瘍の浸潤を認 めていたため右横隔神経を合併切除した (Figure 5)。 そ の後腫瘍を右腕頭静脈から安全に剥離し得たため, 腫瘍 と右肺上葉とを摘出し, 右肺上葉切除を完了した。その 後, 縦隔リンパ節郭清（ND2a-1）を行い, 閉胸し手術を 終了した. 体位変換を含めた手術時間は 4 時間 48 分, 出 血量 $325 \mathrm{ml}$ であり, 無輸血で手術を終了した.

切除標本の肉眼所見: 腫瘍径 $52 \times 35 \times 32 \mathrm{~mm}$. 割面 は, 灰白色充実性の境界明瞭な腫瘤を認めた (Figure 6).

病理組織所見：紡錘形細胞の他に境界不明瞭な $\mathrm{N} / \mathrm{C}$ 比の高い細胞がびまん性に増殖し, 細胞配列の粗密や myxoid な間質を認め, 渦巻き状の配列や核の柵状配列 も認められ, 多核巨細胞や異型核分裂像のほか, 血管周 皮様構造や pseudopalisading necrosis を認め, 明らかな 上皮性悪性腫瘍を示唆する像や横紋筋芽細胞は認めな かった. EVG 染色にて病変は臓側胸膜外に認め, 臓側胸 膜を越える肺内への浸潤を認めなかった (Figure 7). 免 疫染色で, AE1/AE3 陰性, S100 弱陽性, SOX10 陽性, Melan A 陰性, HMB45 陰性, H3K27me3 陰性, STAT6 陰性, CD99 陰性, CAM5.2 陰性, EMA 陰性, neurofilament 陰性であった. 切除断端に悪性細胞を認めず完全 切除したと判断した。組織学的に神経との関係が明確で
はなかったが, 病理組織学的所見および免疫染色の所見 から, 縦隔原発 MPNST と診断した（Figure 8).

術後は合併症もなく, 術後 10 日目に退院した. その後 外来で経過観察中であり, 術後 1 年の現在も自覚症状な く無再発生存中である.

\section{考察}

MPNST (悪性末梢神経鞘腫) は, 悪性軟部組織腫瘍の 約 $5 \%$ を占める稀な悪性腫瘍 2 であり, 四肢体幹部に発生 することが多く, 原発が縦隔内に存在することは稀であ る. 過去の 3 研究によると, 縦隔原発の神経原性腫瘍 775 例のうち, MPNST の症例は 55 例と希少である. $3-5$ ま た, 胸腔内原発 MPNST の中でも後縦隔原発が多く報告 5 されている.もとより縦隔腫瘍の領域の定義は様々な区 分法が存在しており, 国際的に統一された区分法が存在 していなかったが, 近年報告された国際胸腺悪性腫瘍研 究会 (ITMIG) の提唱する縦隔領域の定義6によれば，本 症例の腫瘍の局在は前縦隔ではなく中縦隔 (visceral mediastinum) と定義される。このように新旧の症例報告で 腫瘍の局在を比較することは容易ではないが, 中縦隔領 域に認めるMPNSTとして報告された例7は少ない. MPNST の予後は比較的不良であり, 過去の Wong らの 研究において 5 年生存率は $52 \%$ であり, 局所再発は $49 \%$ ，遠隔転移は $49 \%$ の症例できたすと報告 8 されてい る.また彼らはMPNST の予後予測因子についての研究 で, 多変量解析の結果, 術前放射線治療の導入を行わな かった群と, 切除断端が陰性である群が有意に予後良好 であったことを報告8している. また, 小児 MPNST につ いての Carli らの研究9によると, 完全切除し得た症例群 は 5 年生存率が $82 \%$ であった一方で, 非完全切除となっ 

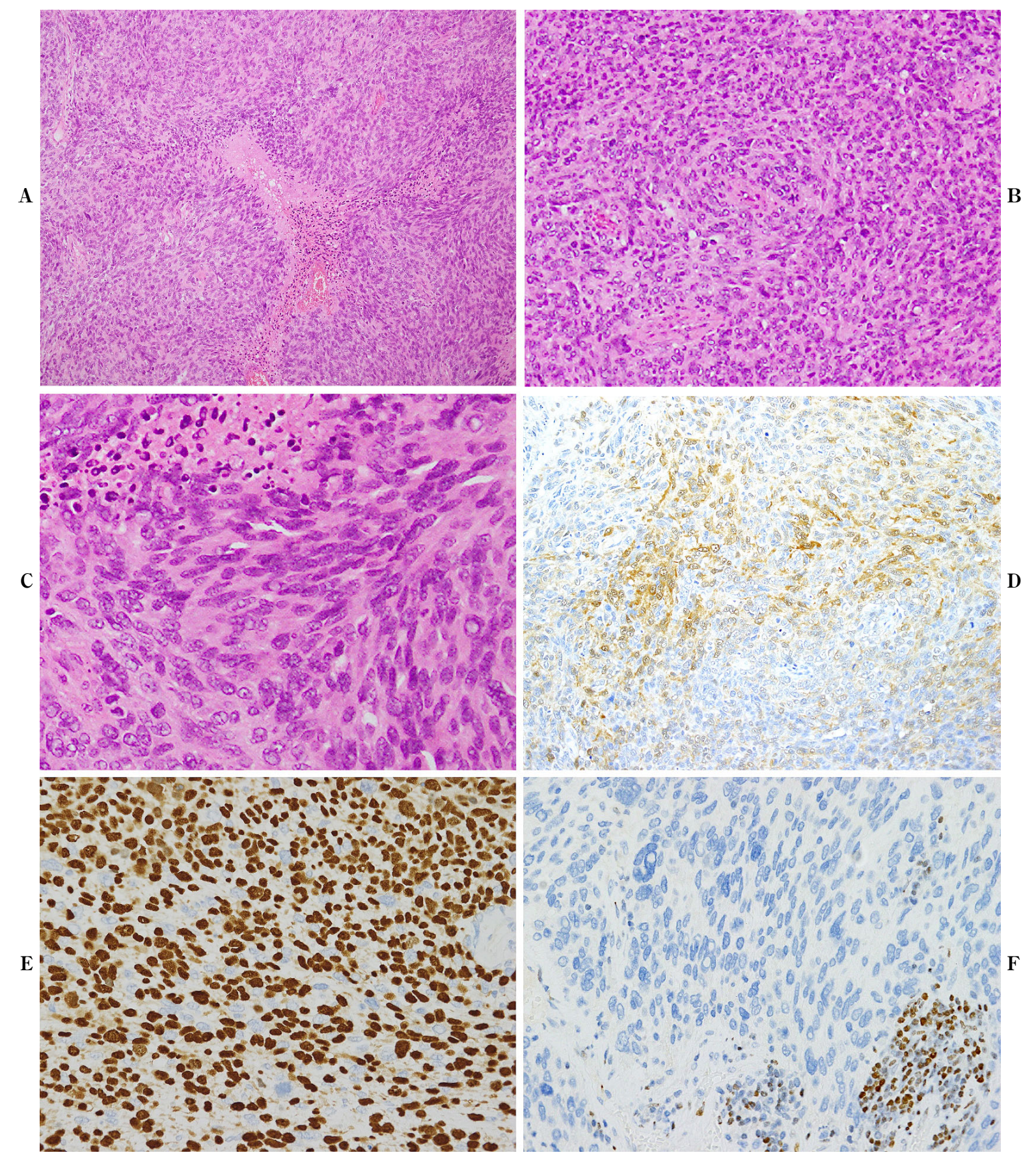

Figure 8. Histopathological findings. A: Hematoxylin-eosin stain $(\times 200)$ shows pseudopalisading necrosis. B: Tumor cells have whorled structures. C: Nuclear palisading is observed. D, E, F: Immunohistochemistry is weakly positive for S100, positive for SOX10, and negative for H3K27me3, respectively.

た症例において術後化学療法を導入してもなお 5 年生存 率は $32 \%$ と予後不良であり, 腫瘍の完全切除を行うこと が治療効果に重要な因子である。縦隔 MPNST に打いて 不完全切除となった 2 症例10,11 は胸膜などへ再発をきた し, 7 ヶ月以内に死亡している. そのため, 本症例のよう に治療前検查に抢いて MPNST の可能性が示唆された
場合は，化学療法の奏効率が低いと想定されるため術前 治療を導入せずに，第一に腫瘍の完全切除を行うことを 考慮すべきである，また過去の報告によると, MPNST の症例の $62.6 \%$ に打いて腫瘍径が $5 \mathrm{~cm}$ 以上 8 であり, 本 症例のように鏡視下での切除が困難である場合が多いた め, 耐術能が十分に担保できる場合は完全切除を遂行す 
るために大血管合併切除や人工血管置換を含む最大限の 術前準備を行うべきである. MPNST の症例において, 特 に切除断端陽性の場合に術後補助療法として化学療法や 放射線療法を行うことが予後を改善させる可能性があ る12 と知られている. 本症例においては完全切除が得ら れたため補助療法を行わない方針としたが, 引き続きの 外来での厳重な経過観察が必要と考えられる. 縦隔 MPNST の予後をさらに改善させるためには, 治療戦略 についてのさらなる研究が必要であると考える.

\section{結 語}

中縦隔原発の MPNST に対して腫瘍切除術を施行し た症例を報告した．治療前検査において MPNST の可能 性が示唆された場合は, 腫瘍の完全切除を行うことを考 慮すべきであり，大血管に隣接した腫瘍の場合は大血管 合併切除や人工血管置換を含む最大限の術前準備を行う べきである.

本論文内容に関連する著者の利益相反：なし

本論文の要旨は第 64 回関西胸部外科学会学術集会にて発 表した.

\section{REFERENCES}

1. Masaoka A, Ito Y, Yasumitsu T. Anterior approach for tumor of the superior sulcus. J Thorac Cardiovasc Surg. 1979;78:413-415

2. Nielsen GP, Antonescu CR, Lothe RA. Malignant peripheral nerve sheath tumour. In: Fletcher CDM, Bridge JA, Hogendoorn PCW, Mertens F, eds. WHO Classification of Tumours of Soft Tissue and Bone. 4th edition. Lyon: IARC Press; 2013:187-189.
3. Sugio $\mathrm{K}$, Inoue $\mathrm{T}$, Inoue $\mathrm{K}$, Tateishi $\mathrm{M}$, Ishida $\mathrm{T}$, Sugimachi K. Neurogenic tumors of the mediastinum originated from the vagus nerve. Eur J Surg Oncol. 1995; 21:214-216.

4. Boland JM, Colby TV, Folpe AL. Intrathoracic peripheral nerve sheath tumors-a clinicopathological study of 75 cases. Hum Pathol. 2015;46:419-425.

5. Ingels GW, Campbell DC Jr, Giampetro AM, Kozub RE, Bentlage CH. Malignant schwannomas of the mediastinum. Report of two cases and review of the literature. Cancer. 1971;27:1190-1201.

6. Carter BW, Tomiyama N, Bhora FY, Rosado de Christenson ML, Nakajima J, Boiselle PM, et al. A modern definition of mediastinal compartments. $J$ Thorac Oncol. 2014;9(Suppl 2):S97-S101.

7. Koezuka S, Hata Y, Sato F, Otsuka H, Makino T, Tochigi $\mathrm{N}$, et al. Malignant peripheral nerve sheath tumor in the anterior mediastinum: A case report. Mol Clin Oncol. 2014;2:987-990.

8. Wong WW, Hirose T, Scheithauer BW, Schild SE, Gunderson LL. Malignant peripheral nerve sheath tumor: analysis of treatment outcome. Int J Radiat Oncol Biol Phys. 1998;42:351-360.

9. Carli M, Ferrari A, Mattke A, Zanetti I, Casanova M, Bisogno G, et al. Pediatric malignant peripheral nerve sheath tumor: the Italian and German soft tissue sarcoma cooperative group. J Clin Oncol. 2005;23:8422-8430.

10. Ducatman BS, Scheithauer BW. Malignant peripheral nerve sheath tumors with divergent differentiation. Cancer. 1984;54:1049-1057.

11. Otani Y, Morishita Y, Yoshida I, Ishikawa S, Otaki A, Aihara T, et al. A malignant Triton tumor in the anterior mediastinum requiring emergency surgery: report of a case. Surg Today. 1996;26:834-836.

12. Cai Z, Tang X, Liang H, Yang R, Yan T, Guo W. Prognosis and risk factors for malignant peripheral nerve sheath tumor: a systematic review and meta-analysis. World J Surg Oncol. 2020;18:257. 